\title{
HYBRID MAIZE AND SWEET POTATO INTERCROPPING: A TECHNOLOGY TO INCREASE PRODUCTIVITY AND PROFITABILITY FOR POOR HILL FARMERS IN BANGLADESH
}

\author{
M. N. Islam ${ }^{* 1}$, M. Akhteruzzaman ${ }^{2}$, M. S. Alom ${ }^{3}$ and M. Salim ${ }^{4}$ \\ Bangladesh Agricultural Research Institute, Joydebpur, Gazipur-1701, Bangladesh
}

\begin{abstract}
The experiment was conducted at the Hill Agricultural Research Station, Khagrachari during two winter seasons of 2010-11 and 2011-12 to find out suitable planting system of the component crops for increasing productivity and profitibility for hill farmers of Bangladesh. Three intercrop combinations viz., (i) maize paired row +2 rows sweet potato, (ii) maize normal row +1 row sweet potato and (iii) sweet potato normal row +1 row maize were evaluated against their respective sole crops. In all combinations, light availability was more at early growth stage and reduced gradually with the advancement of canopy development of maize. Light availability was minimum at 100 days after emergence and thereafter slightly increased in three intercrop combinations. Among intercrop combinations, light availability to sweet potato canopy was more in maize paired row +2 rows sweet potato combination through out the crop period which enhance tuber formation, tuber bulging and tuber yield. Contrary, sweet potato vines provide a mulch cover for maize which preserve soil moisture and reduce weed infestation producing higher yield and yield components of maize. Maize yield (cob yield: 19.82 $\mathrm{t} \mathrm{ha}^{-1}$, grain yield: $\left.8.98 \mathrm{t} \mathrm{ha}^{-1}\right)$, tuber yield of sweet potato $\left(17.11 \mathrm{t} \mathrm{ha}^{-1}\right)$ and maize equivalent yield (cob equivalent yield: $42.63 \mathrm{t} \mathrm{ha}^{-1}$, grain equivalent yield: $15.82 \mathrm{t} \mathrm{ha}^{-1}$ ) were the highest in maize paired row +2 rows sweet potato combination. Similarly, the highest gross return (for cob: Tk. 1,27,890 ha ${ }^{-1}$, for grain: Tk. 1,58,200 ha ${ }^{-1}$ ), gross margin (for cob: Tk. $87,890 \mathrm{ha}^{-1}$, for grain: Tk.1,08,200 ha ${ }^{-1}$ ) and benefit cost ratio (for cob: 3.20, for grain: 3.16) were also obtained from the same combination. The results revealed that maize paired row +2 rows sweet
\end{abstract}

\footnotetext{
" Corresponding author email: drmdnurulislam@yahoo.com

${ }^{1}$ Principal Scientific Officer, Agronomy Division, Bangladesh Agricultural Research Institute (BARI)

${ }^{2}$ Principal Scientific Officer, Agronomy Division, BARI

${ }^{3}$ Principal Scientific Officer, Agronomy Division, BARI

${ }^{4}$ Scientific Officer, Hill Agricultural Research Station, Khagrachari
} 
potato combination might be suitable for increasing productivity and ensure food security for resource poor hill farmers of Bangladesh.

Key words: Hill farmers, Hybrid maize, Sweet potato, Intercropping, Productivity and Technology

\section{INTRODUCTION}

Chittagong Hill Tracts region in Bangladesh lies within $21.25^{\circ}$ to $23.45^{\circ}$ North latitude and $91.45^{\circ}$ to $92.50^{\circ}$ East longitudes. The total area of this region is estimated to be $13295 \mathrm{~km}^{2}$, which is approximately one tenth of the country area (Baten et al., 2009) and about 1.60 million people live there (BBS, 2013). Arable land in hilly areas is continuously being sub-divided into small holdings in the face of increasing population pressure. Majority of the hill families live below the poverty line and have lack money to buy foods from the market (Khandaker et al., 2009). Hence, it is necessary to encourage farmers to adopt innovative integrated crop intensification approaches to increase productivity of their lands. Intercropping is one of the cropping strategies that have been recognized to improve the food security situation and incomes for the farmers (Mahfuza, 2012). Intercropping also helps to reduce weed populations, insect pest's infestation and risk of complete crop failure (Amede, 2001; Islam et al., 2013).

Intercropping system becomes more productive and profitable when it is done properly by selecting compatible crops (Begum et al., 2010), spatial arrangements and population density of component crops (Islam et al., 2006) and judicious application of chemical fertilizers (Basak, 2008). Hybrid maize-sweet potato intercropping is compatible as they possess different photosynthetic pathways, different growth habit and requirement of different growth resources (Islam et al., 2007). This system may be popular in hilly areas for their high yield potential. Both the crops have diversified uses. Roasted maize cobs at dent stage are popular to hill peoples than other uses. Generally, hill farmers grow hybrid maize and sweet potato in hill valleys as sole crops. In that region, productivity and profitability may be increased through growing hybrid maize and sweet potato as intercropping. Hence, the experiment was conducted to find out the suitable planting system of hybrid maize-sweet potato intercropping system for increasing productivity for hill farmers in Bangladesh.

\section{MATERIALS AND METHODS}

The experiment was conducted at the valley of Hill Agricultural Research Station, Khagrachari, Bangladesh during two consecutive winter seasons of 2010-11 and 2011-12. The soil of the experimental field was clay loam in texture and strongly acidic in reaction ( $\mathrm{pH} 4.6)$ under Agro-Ecological Zone-29. The soil was medium in organic matter content $(1.88 \%)$, very low status in total $\mathrm{N}(0.09 \%)$, low in $\mathrm{P}(5.4 \mu \mathrm{g}$ $\left.\mathrm{g}^{-1}\right)$, medium in $\mathrm{K}\left(0.24\right.$ meq $\left.100 \mathrm{~g}^{-1}\right)$, medium in $\mathrm{S}\left(16 \mu \mathrm{g} \mathrm{g}^{-1}\right)$, low in $\mathrm{Zn}\left(0.78 \mu \mathrm{g} \mathrm{g}^{-1}\right)$ 
and low in $\mathrm{B}\left(0.25 \mathrm{\mu g} \mathrm{g}^{-1}\right)$. The crops received total rainfall of $15.1 \mathrm{~mm}$ and $4.2 \mathrm{~mm}$ during crop period of 2010-11 and 2011-12, respectively. The monthly mean maximum and minimum air temperature were $26.1^{\circ} \mathrm{C}$ and $19.1^{\circ} \mathrm{C}$, respectively during 2010-11 while $25.9^{\circ} \mathrm{C}$ and $20.4^{\circ} \mathrm{C}$, respectively in $2011-12$. Five treatments were evaluated such as: $\mathrm{T}_{1}=$ Maize paired rows $(37.5 \mathrm{~cm} / 150 \mathrm{~cm} / 37.5 \mathrm{~cm} \times 25 \mathrm{~cm})+2$ rows sweet potato $(60 \mathrm{~cm} \times 30 \mathrm{~cm})$ in between two maize paired row $(100 \%$ MPR: $40 \% \mathrm{SP}), \mathrm{T}_{2}=$ Maize normal row $(75 \mathrm{~cm} \times 25 \mathrm{~cm})+1$ row sweet potato in between two maize rows $(100 \%$ MNR: $60 \% \mathrm{SP}), \mathrm{T}_{3}=$ Sweet potato normal row $(60 \mathrm{~cm})+1$ row maize after 2 rows sweet potato $(100 \%$ SP: $50 \% \mathrm{MNR}), \mathrm{T}_{4}=$ Sole maize $(75 \times$ $25 \mathrm{~cm}), \mathrm{T}_{5}=$ Sole sweet potato $(60 \mathrm{~cm} \times 30 \mathrm{~cm})$. The experiment was laid out in a randomized complete block design with five replications. The unit plot size was 4.5 $\mathrm{m} \times 6.0 \mathrm{~m}$. The hybrid maize (var. BARI Hybrid maize 9) and sweet potato (var. BARI Mishtialu-7) were used in this experiment. BARI Hybrid maize 9 is a high yield potential (grain: 10-11 t ha ${ }^{-1}$ ) cereal crop and can be grown in hill eco-system. It is moderately drought tolerant. On the contrary, BARI Mishtialu-7 is a high yielding variety (tuber yield: $40-45 \mathrm{t} \mathrm{ha}^{-1}$ ), rich in vitamin A. It is also moderately drought tolerant. Seeds of maize and vines of sweet potato were sown or planted on 7 December 2010 and 2011 according to treatments. Sole hybrid maize and intercropping treatments were fertilized with 260-55-110-40-4-1 $\mathrm{kg} \mathrm{ha}^{-1}$ NPKSZnB while sole sweet potato with 100-40-100-10-1 $\mathrm{kg} \mathrm{ha}^{-1}$ NPKSZn (FRG, 2005). The full amount of P K S Zn B and $1 / 3 \mathrm{~N}$ were applied as basal in the form of triple super phosphate, muriate of potash, gypsum, zinc sulphate, boric acid and urea, respectively. The remaining $\mathrm{N}$ was top dressed in two equal splits at 30 and 60 days after sowing (DAS). Irrigation was given after sowing or planting for proper establishment of crops. Subsequently three irrigations were applied at 30,60 and 90 DAS. Two hand weeding were done at 20 and 40 DAS to keep the crops reasonably weed free. Each maize plots were divided into two halves of $4.5 \mathrm{~m} \times 3.5 \mathrm{~m}\left(5.75 \mathrm{~m}^{2}\right)$ for harvesting the cobs. Plants $\mathrm{m}^{-2}$ for both the crops was recorded from randomly selected three places and yield components from 5 plants at harvest. Maize cobs of were harvested at dent stage (135-140 DAS) and physiological maturity stage (155160 DAS) at both the years. On the other hand, sweet potato was harvested at maturity stage (156 DAP). Yields of both the crops were taken from whole plot. Maize equivalent yield was computed by converting yield of intercrops on the basis of prevailing market price of individual crop following the formula of Bandyopadhyay (1984) as given below:

$$
M e q=\text { Yim }+\frac{\text { Yisp } x \text { Psp }}{P m} \quad \text { Where, } M e q=\text { Maize equivalent yield }
$$

Yim $=$ Yield of intercrop maize, Yisp =Yield of intercrop sweet potato

$P m=$ Price of maize, $P s p=$ Price of sweet potato 
Data on yield and yield components of both the crops for two consecutive years showed similar trend. So, those data were pooled and means were adjudged by LSD test at 5\% level of significance. Benefit cost analysis was also done.

\section{RESULTS AND DISCUSSION}

\section{Availability of light on sweet potato canopy}

Spatial arrangement of maize influenced light availability to under storey sweet potato. Light availability on sole maize and sole sweet potato was $100 \%$ through out the growing period as there was no shade due to intercropping. So, light availability on both the sole crops was not shown in Figure 1. Regardless of planting systems, light availability was $100 \%$ upto 20 days after sowing (DAS), and then it was reduced gradually with the advancement of canopy development of maize (Figure 1). At 40 DAS, sweet potato in maize paired row +2 row sweet potato combination received almost full light $(96 \%)$ which was followed by sweet potato normal row +1 row maize $(93 \%)$ and maize normal row +1 row sweet potato combination $(91 \%)$; and thereafter it decreased over time due to advancement of canopy development of maize reaching minimum level at 100 DAS. At 100 DAS, sweet potato in maize paired row +2 row sweet potato combinations got 36\% light followed by sweet potato normal row +1 row maize combination $(25 \%)$. Light availability on sweet potato canopy was minimum in maize normal row +1 row sweet potato combination (12\%). Then light availability increased to sweet potato crop due to leaf senescence of maize in all treatments. At $140 \mathrm{DAS}$, light availability on sweet potato canopy was 40,31 and $18 \%$ in maize paired row +2 row sweet potato, sweet potato normal row +1 row maize and maize normal row +1 row sweet potato combination, respectively. Light availability to sweet potato canopy was more in maize paired row +2 rows sweet potato combination through out the crop period due to widest maize spacing $(150 \mathrm{~cm})$ which was followed by sweet potato normal row +1 row maize $(120 \mathrm{~cm})$. On the other hand, availability of light on sweet potato canopy was the lowest in maize normal row $(75 \mathrm{~cm})+1$ row sweet potato combinations. Availability of more light on sweet potato canopy through out the crop period enhance tuber formation, tuber bulging and ultimately tuber yield. Alternately, sweet potato vines provide a mulch cover for maize which preserve more soil moisture, reduce weed infestation and accelerate maize growth producing more no. of cobs or grain yield. Islam (2002) also stated similar results in case of maize-bush bean intercropping system under different spatial arrangement.

\section{Effect on maize yield and yield attributes}

Plants $\mathrm{m}^{-2}$, cob weight with husk per plant, single cob weight with husk and cob yield with husk of hybrid maize were influenced significantly due to intercropping with sweet potato under different planting systems (Table 1). Plant population $\mathrm{m}^{-2}$ of maize varied mainly due to planting systems. Higher and similar trend of plants $\mathrm{m}^{-2}$ of maize was recorded in sole maize (5.2), maize paired row +2 
rows sweet potato (5.3) and maize normal row +1 row sweet potato (5.0) whereas the lowest plants $\mathrm{m}^{-2}$ of maize (2.3) was observed in sweet potato normal row +1 row maize (120 cm apart rows) combinations. The maximum cob weight with husk per plant $(508.8 \mathrm{~g})$ was recorded in maize paired row +2 row sweet potato which was at par with sweet potato normal row +1 row maize $(498.7 \mathrm{~g})$ where maize sown in $120 \mathrm{~cm}$ apart rows. Higher cob weight per plant in aforesaid treatments were observed might be due to lower intra or inter species competition as well as more soil moisture preservation by sweet potato vines. The lowest cob weight with husk per plant $(441.4 \mathrm{~g})$ was found from sole maize which was statistically similar to maize normal row +1 row sweet potato combination (448.6 g). Weight of single cob with husk $(318.0 \mathrm{~g})$ was maximum in maize paired row +2 rows sweet potato which was followed by sole maize $(315.3 \mathrm{~g})$ and sweet potato normal row +1 row maize $(3.11 .7 \mathrm{~g})$ combination, while the lowest weight $(299.1 \mathrm{~g})$ was recorded in maize normal row +1 row sweet potato. The maximum cob yield with husk $\left(19.82 \mathrm{t} \mathrm{ha}^{-1}\right)$ was found in maize paired row +2 rows sweet potato which was at par to sole maize $\left(18.36 \mathrm{t} \mathrm{ha}^{-1}\right)$ and maize normal row +1 row sweet potato combination $\left(17.94 \mathrm{t} \mathrm{ha}^{-1}\right)$. Higher cob yield with husk in maize paired row +2 rows sweet potato was attributed to the cumulative effect of yield components of maize. This result is in agreement with the finds of Basak et al. (2008). The lowest cob yield with husk $\left(9.18 \mathrm{t} \mathrm{ha}^{-1}\right)$ was recorded in sweet potato normal row +1 row maize due to mainly minimum plants $\mathrm{m}^{-2}$.

Plants $\mathrm{m}^{-2}$ and grain yield of hybrid maize differed significantly in maize-sweet potato intercropping under different planting systems (Table 2). The variation in planting systems was the main reason for the variation in plants $\mathrm{m}^{-2}$ of maize in different treatment combinations of maize-sweet potato intercropping. The maximum grain yield $\left(8.98 \mathrm{t} \mathrm{ha}^{-1}\right)$ of maize was produced from maize paired row +2 rows sweet potato which was at par with sole maize $\left(8.01 \mathrm{t} \mathrm{ha}^{-1}\right)$ while the lowest $(4.04 \mathrm{t}$ $\mathrm{ha}^{-1}$ ) from sweet potato normal row +1 row maize. Yield variations in different intercropping systems were occurred due to variation in plants $\mathrm{m}^{-2}$ as well as other yield attributes. Similar results were reported by Islam et al. (2006). Similar to grain yield, stover yield of maize was recorded as the highest in maize paired row +2 rows sweet potato $\left(13.21 \mathrm{t} \mathrm{ha}^{-1}\right)$ which was identical with sole maize $\left(12.46 \mathrm{t} \mathrm{ha}^{-1}\right)$ and maize normal row +1 row sweet potato $\left(12.00 \mathrm{t} \mathrm{ha}^{-1}\right)$. The minimum stover yield $\left(5.97 \mathrm{t} \mathrm{ha}^{-1}\right)$ was found from sweet potato normal row +1 row maize combination.

\section{Effect on sweet potato yield and yield attributes}

Plant population $\mathrm{m}^{-2}$, number of tubers per plant, tuber weight per plant, single tuber weight and tuber yield of sweet potato were affected significantly in maizesweet potato intercropping under different planting systems (Table 3 ). The maximum plants $\mathrm{m}^{-2}$ was recorded in sole sweet potato (4.5) which was identical to sweet potato normal row +1 row maize (4.3). The lowest plant population $\mathrm{m}^{-2}$ was found in maize paired row +2 rows sweet potato (2.9) and it was at par with maize normal 
row +1 row sweet potato combination (3.2). The significant variation in plants $\mathrm{m}^{-2}$ was attributed mainly due to planting system. The highest number of tubers per plant was recorded in maize paired row +2 rows sweet potato (4.5) possibly due to less inter crop competition. Number of tubers per plant decreased with increasing crop competition and the minimum number of tubers per plant was obtained from maize normal row +1 row sweet potato combination (2.6). Like tuber weight per plant, tuber size i.e. single tuber weight decreased with the increase of crop competition for growth resources and it followed similar trend like tuber weight per plant. The maxumum tuber yield $\left(17.11 \mathrm{t} \mathrm{ha}^{-1}\right)$ of sweet potato was recorded in maize paired row +2 rows sweet potato (Table 3 ) which was statistically similar to sole sweet potato $\left(16.98 \mathrm{tha}^{-1}\right)$. On the contrary, tuber yield of sweet potato was the lowest $(7.18$ $\mathrm{t} \mathrm{ha}^{-1}$ ) in maize normal row +1 row sweet potato combination. Tuber yield in different intercrop combinations was attributed to the cumulative effect of yield components. These results are in conformity with the finds of Islam et al. (2007).

\section{Intercrop efficiency based on equivalent yield and benefit cost}

Total productivity in terms of maize cob equivalent yields and economic study of hybrid maize-sweet potato intercropping under different planting systems are presented in table 4. Maize cob equivalent yields in all intercropping systems were more than sole maize or sole sweet potato. Among intercropping systems, the highest maize cob equivalent yield $\left(42.63 \mathrm{tha}^{-1}\right)$ was recorded in maize paired row +2 rows sweet potato combination which was much higher than other combinations. The highest maize cob equivalent yield in this combination was observed because of the higher accumulated yield of maize cob and sweet potato tuber. This result is in line with the findings of Uddin et al. (2006). The lowest maize cob equivalent yield $\left(18.36 \mathrm{t} \mathrm{ha}^{-1}\right)$ was obtained from sole maize. Gross return followed the trend similar to maize cob equivalent yield. Cost of production differed in different planting systems due to involvement of different variable costs. The highest gross margin was obtained from maize paired row +2 rows sweet potato combination (Tk. $87,890 \mathrm{ha}^{-1}$ ). Though the cost of production of this combination was higher than the sole crop but highest gross margin was recorded due to the highest gross return. The highest benefit cost ratio (3.20) was also recorded maize paired row +2 rows sweet potato indicating profitable combination of maize sweet potato intercropping systems. Other two intercrop combinations failed to show higher benefit than sole sweet potato but higher than sole maize.

Total productivity in terms of maize grain equivalent yields and economic study of hybrid maize-sweet potato intercropping systems were also computed and are presented in table 5. The highest maize grain equivalent yield $\left(15.82 \mathrm{t} \mathrm{ha}^{-1}\right)$ was recorded in maize paired row +2 rows sweet potato which was $50 \%$ higher than maize normal row +1 row sweet potato $\left(10.72 \mathrm{t} \mathrm{ha}^{-1}\right)$. Gross return (Tk. 1,58,200

$\mathrm{ha}^{-1}$ ), gross margin (Tk. 1,08,200 ha ${ }^{-1}$ ) and benefit cost ratio (3.16) were also highest in maize paired row +2 row sweet potato. 
Sole sweet potato showed higher BCR than maize normal row +1 row sweet potato but much higher than sweet potato normal row +1 row maize. Maize as sole crop failed to show higher benefit than all other combinations so maize as sole crop could be easily replaced by intercropping system. Similar trend was reported by Begum et al. (2010); Islam et al. (2013).

\section{CONCLUSION}

The results revealed that maize paired row +2 rows sweet potato combination could be suitable for increasing productivity and profitability for hill farmers of Khagrachari in Bangladesh.

\section{REFERENCES}

Amede, T. and Nigatu, Y. 2001. Interaction of Components of Sweetpotato-maize Intercropping under the Semi-arid conditions of the Rift-Valley, Ethiopia. Tropical Agriculture, 78(1): 1-7

Bandyopadhyay, S.N. 1984. Nitrogen and water relations in grain sorghum-legume intercropping systems. Ph. D. Dissertation, Indian Agricultural Research Institute, New Delhi

Basak, N.C., Quayyum, M. A., Uddin, M. J., Islam, M. N. and Mozumder, S.N. 2008. Intercropping bushbean with hybrid maize at different planting geometry and fertilizer levels. Bangladesh Journal of Agriculture and Environment, 4(2): 101-106

Baten, M.A., Khan, N. A., Ahammad, R. and Misbahuzzaman, K. 2009. Village Common Forests in Chittagong Hill Tracts, Bangladesh: Balance between Conservation and Exploitation. The paper presented at First International Community Forestry Conference held in Nepal on 15-18 September 2009

BBS (Bangladesh Bureau of Statistics). 2013. Statistical Yearbook of Bangladesh, Bangladesh Bureau of Statistics, Statistics and informatics Division, Ministry of Planning, Government of the People's Republic of Bangladesh, Dhaka.p. 35

Begum, S., Islam, M.N., Rahman, M. T., Chowdhury, J. A. and Haque, M.I. 2010. Suitability study of different chili varieties for intercropping with sweet gourd. Journal of Experimental Biosciences, 1(2): 1-4

FRG. 2005. Fertilizer Recommendation Guide-2005. Bangladesh Agricultural Research Council (BARC), Farmgate, New Airport Road, Dhaka-1215

Islam, M. N., Hossain, M.A., Khan, M.S.A., Nag, B.L., Sarker, M.A.I., Rahman, M.T. and Ahmed, I. M. 2007. Fertilizer management in hybrid maize-sweet potato intercropping systems. Bangladesh Journal of Crop Science, 18 (1): 89-94

Islam, M. N., Haque, M.M. and Hamid, A. 2004. Spatial arrangement and population density effects on productivity of maize-bushbean intercropping systems. Bangladesh Journal of Agricultural Research, 29 (3): 467-474

Islam, M. N., Haque, M.M. and Hamid, A. 2006. Planting arrangement and population density effects on the physiological attributes and productivity of maize-bushbean intercropping systems. Bangladesh Journal of Agricultural Research, 31(3):353-364 
Islam, M.N., Rahman, M. S., Ahmed, F., Alom, M.S. and Akhteruzzaman, M. 2013. Performance of different HYV mustard varieties with sugarcane (Sacchaarum officinarum) as intercrop in farmers' fields. Bangladesh Journal of Agricultural Research, 38(1): 137-143

Khandaker, S.R., Bakht, Z. and Koolwal, G.B. 2009. The poverty impacts of rural roads. Economic development and Cultural Change, 57: 685-772

Mahfuza, S.N., Islam, M.N., Hannan, A., Akhteruzzaman, M.and Begum, S. 2012. Intercropping different vegetables and spices with pointed gourd. Journal of Experimental Biosciences, 3(1): 77-82

Uddin, M.J., Quayyum, M. A., Islam, M. N. and Basak, N. C. 2006. Intercropping of hybrid maize with bush bean at different fertilizer levels. Bangladesh Journal of Agriculture and Environment, 2(2): 17-22 
Table 1: Cob with husk yield and yield components of hybrid maize as sole and intercropping systems (pooled data of 2010-11 and 2011-12)

\begin{tabular}{l|l|l|l|l|l}
\hline Treatment & $\begin{array}{l}\text { Plants }^{-2} \\
\text { (no.) }\end{array}$ & $\begin{array}{c}\text { Cobs plant }^{-1} \\
\text { (no.) }\end{array}$ & $\begin{array}{c}\text { Cob weight } \\
\text { with husk } \\
\text { plant }\end{array}$ & $\begin{array}{c}\text { Single cob } \\
\text { weight with } \\
\text { husk } \\
(\mathbf{g})\end{array}$ & $\begin{array}{c}\text { Cob yield } \\
\text { with husk } \\
\left.\text { (t ha }^{-1}\right)\end{array}$ \\
\hline $\mathrm{T}_{1}$ & 5.3 & 1.6 & 508.8 & 318.0 & 19.82 \\
$\mathrm{~T}_{2}$ & 5.0 & 1.5 & 448.6 & 299.1 & 17.94 \\
$\mathrm{~T}_{3}$ & 2.3 & 1.6 & 498.7 & 311.7 & 9.18 \\
$\mathrm{~T}_{4}$ & 5.2 & 1.4 & 441.4 & 315.3 & 18.36 \\
$\mathrm{LSD}_{(0.05)}$ & 0.6 & 0.1 & 30.1 & 14.1 & 2.45 \\
$\mathrm{CV}(\%)$ & 9.7 & 4.8 & 4.6 & 3.3 & 10.9 \\
\hline
\end{tabular}

$\mathrm{T}_{1}=$ Maize paired row +2 rows sweet potato, $\mathrm{T}_{2}=$ Maize normal row +1 row sweet potato, $\mathrm{T}_{3}=$ Sweet potato normal row +1 row maize, $\mathrm{T}_{4}=$ Sole maize

Table 2: Grain yield and yield components of hybrid maize in maize sole and intercropping systems (pooled data of 2010-11 and 2011-12)

\begin{tabular}{|c|c|c|c|c|c|c|}
\hline Treatment & $\begin{array}{c}\text { Plants } \\
\mathbf{m}^{-2} \\
\text { (no.) }\end{array}$ & $\begin{array}{c}\text { Cobs } \\
\text { plant }^{-1} \\
(\text { no. })\end{array}$ & $\begin{array}{c}\text { Grains } \\
\text { cob }^{-1} \\
\text { (no.) }\end{array}$ & $\begin{array}{c}\text { 1000- } \\
\text { grain } \\
\text { weight } \\
\text { (g) }\end{array}$ & $\begin{array}{c}\text { Grain yield } \\
\qquad\left(\mathrm{t} \mathrm{ha}^{-1}\right)\end{array}$ & $\begin{array}{c}\text { Stover } \\
\text { yield } \\
\left(\mathbf{t ~ h a}^{-1}\right)\end{array}$ \\
\hline $\mathrm{T}_{1}$ & 5.3 & 1.6 & 471 & 357.0 & 8.98 & 13.21 \\
\hline $\mathrm{T}_{2}$ & 5.0 & 1.5 & 452 & 345.8 & 7.85 & 12.00 \\
\hline $\mathrm{T}_{3}$ & 2.3 & 1.6 & 463 & 354.3 & 4.04 & 5.97 \\
\hline $\mathrm{T}_{4}$ & 5.2 & 1.4 & 469 & 350.2 & 8.01 & 12.46 \\
\hline $\operatorname{LSD}_{(0.05)}$ & 0.6 & 0.1 & 23 & 14.1 & 1.12 & 1.86 \\
\hline $\mathrm{CV}(\%)$ & 9.7 & 4.8 & 3.7 & 2.9 & 11.3 & 12.4 \\
\hline
\end{tabular}

$\mathrm{T}_{1}=$ Maize paired row +2 rows sweet potato, $\mathrm{T}_{2}=$ Maize normal row +1 row sweet potato, $\mathrm{T}_{3}=$ Sweet potato normal row +1 row maize, $\mathrm{T}_{4}=$ Sole maize 
Table 3: Tuber yield and yield components of sole sweet potato and intercropping systems (pooled data of 2010-11 and 2011-12)

\begin{tabular}{l|l|l|l|l|l}
\hline Treatment & $\begin{array}{c}\text { Plants }^{-2} \\
(\mathbf{n o .})\end{array}$ & $\begin{array}{c}\text { Tubers }_{\text {plant }^{-1}} \\
(\mathbf{n o .})\end{array}$ & $\begin{array}{c}\text { Tuber weight } \\
\text { plant }^{-1} \\
(\mathbf{g})\end{array}$ & $\begin{array}{c}\text { Single tuber } \\
\text { weight } \\
(\mathbf{g})\end{array}$ & $\begin{array}{c}\text { Tuber yield } \\
\left(\mathbf{t ~ h a}^{-\mathbf{1}}\right)\end{array}$ \\
\hline $\mathrm{T}_{1}$ & 2.9 & 4.5 & 767.0 & 170.4 & 17.11 \\
$\mathrm{~T}_{2}$ & 3.2 & 2.6 & 299.2 & 115.0 & 7.18 \\
$\mathrm{~T}_{3}$ & 4.3 & 2.8 & 339.3 & 121.2 & 10.94 \\
$\mathrm{~T}_{5}$ & 4.5 & 3.1 & 503.1 & 162.3 & 16.98 \\
$\mathrm{LSD}_{(0.05)}$ & 0.4 & 0.1 & 17.8 & 4.3 & 1.85 \\
$\mathrm{CV}(\%)$ & 8.2 & 3.1 & 2.7 & 2.2 & 10.3 \\
\hline
\end{tabular}

$\mathrm{T}_{1}=$ Maize paired row +2 rows sweet potato, $\mathrm{T}_{2}=$ Maize normal row +1 row sweet potato, $\mathrm{T}_{3}=$ Sweet potato normal row +1 row maize, $T_{5}=$ Sole sweet potato

Table 4: Cob equivalent yield and benefit cost analysis of sole maize and intercropping system (pooled data of 2010-11 and 2011-12)

\begin{tabular}{l|c|c|c|c|c}
\hline Treatment & $\begin{array}{c}\text { Maize cob } \\
\text { equivalent yield } \\
\left(\mathbf{t ~ h a}^{\mathbf{- 1}}\right)\end{array}$ & $\begin{array}{c}\text { Gross } \\
\text { return } \\
\left(\mathbf{T k ~ h a ~}^{-\mathbf{1}} \mathbf{)}\right.\end{array}$ & $\begin{array}{c}\text { Cost of } \\
\text { production } \\
\left(\mathbf{T k ~ h a}^{-\mathbf{1}}\right)\end{array}$ & $\begin{array}{c}\text { Gross } \\
\text { margin } \\
\left(\mathbf{T k ~ h a}^{-\mathbf{1}} \mathbf{)}\right.\end{array}$ & BCR \\
\hline $\mathrm{T}_{1}$ & 42.63 & 127890 & 40000 & 87890 & 3.20 \\
$\mathrm{~T}_{2}$ & 27.51 & 82530 & 40000 & 42530 & 2.06 \\
$\mathrm{~T}_{3}$ & 23.77 & 71310 & 40000 & 31310 & 1.78 \\
$\mathrm{~T}_{4}$ & 18.36 & 55080 & 38000 & 17080 & 1.45 \\
$\mathrm{~T}_{5}$ & 22.64 & 67920 & 28500 & 39420 & 2.38 \\
\hline
\end{tabular}

$\mathrm{T}_{1}=$ Maize paired row +2 rows sweet potato, $\mathrm{T}_{2}=$ Maize normal row +1 row sweet potato, $\mathrm{T}_{3}=$ Sweet potato normal row +1 row maize, $\mathrm{T}_{4}=$ Sole maize, $\mathrm{T}_{5}=$ Sole sweet potato Local market price $\left(\mathrm{Tk}_{\mathrm{kg}}{ }^{-1}\right)$ : Maize cob: 3/-, Sweet potato: 4/- 
Table 5: Maize grain equivalent yield and benefit cost analysis of sole maize and intercropping system (pooled data of 2010-11 and 2011-12)

\begin{tabular}{|c|c|c|c|c|c|}
\hline Treatment & $\begin{array}{c}\text { Maize grain } \\
\text { equivalent yield } \\
\left(\mathrm{t} \mathrm{ha}^{-1}\right)\end{array}$ & $\begin{array}{c}\text { Gross } \\
\text { return } \\
\left(\mathrm{Tk} \mathrm{ha}^{-1}\right)\end{array}$ & $\begin{array}{c}\begin{array}{c}\text { Cost of } \\
\text { production }\end{array} \\
\left(\mathrm{Tk} \mathrm{ha}^{-1}\right)\end{array}$ & $\begin{array}{c}\text { Gross } \\
\text { margin } \\
\left(\mathbf{T k}^{-1} \mathbf{h a}^{-1}\right)\end{array}$ & BCR \\
\hline $\mathrm{T} 1$ & 15.82 & 158200 & 50000 & 108200 & 3.16 \\
\hline $\mathrm{T} 2$ & 10.72 & 107200 & 50000 & 57200 & 2.14 \\
\hline $\mathrm{T} 3$ & 8.42 & 84200 & 50000 & 34200 & 1.68 \\
\hline $\mathrm{T} 4$ & 8.01 & 80100 & 48000 & 32100 & 1.67 \\
\hline T5 & 6.79 & 67900 & 28500 & 39400 & 2.38 \\
\hline
\end{tabular}

$\mathrm{T}_{1}=$ Maize paired row +2 rows sweet potato, $\mathrm{T}_{2}=$ Maize normal row +1 row sweet potato, $\mathrm{T}_{3}=$ Sweet potato normal row +1 row maize, $\mathrm{T}_{4}=$ Sole maize, $\mathrm{T}_{5}=$ Sole sweet potato Local market price $\left(\mathrm{Tk} \mathrm{kg}^{-1}\right)$ : Maize grain: 10/-, Sweet potato: 4/-

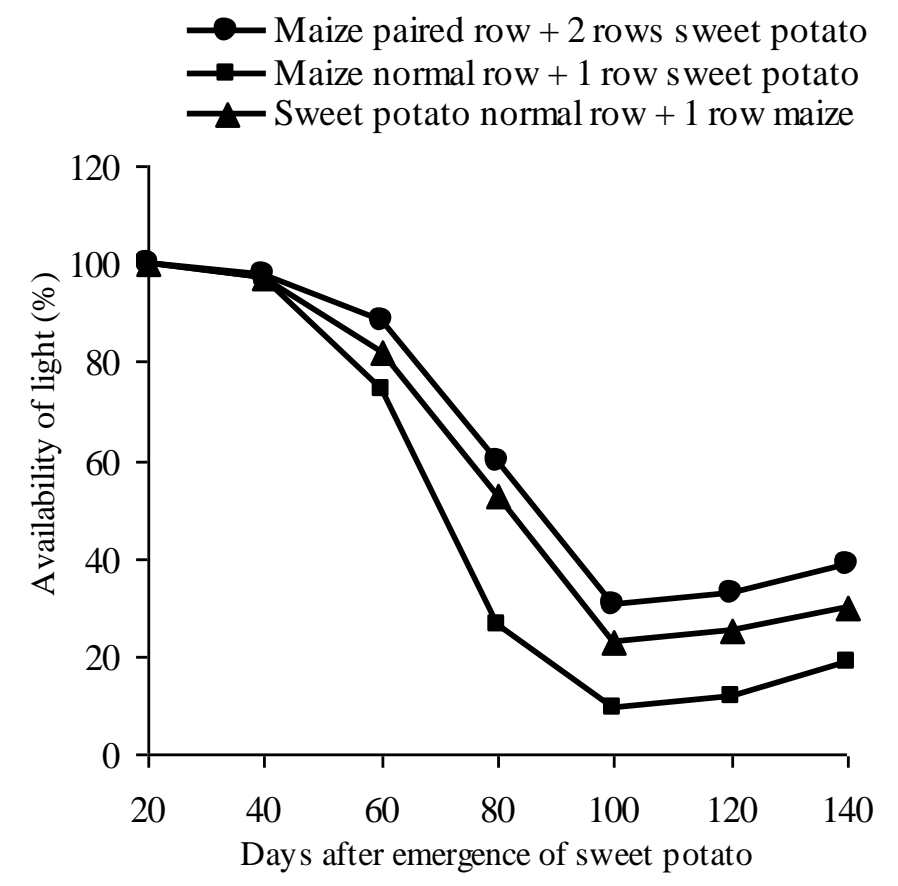

Figure 1: Availability of light on sweet potato in maize/sweet potato intercropping 